\title{
Prevalence and taxonomic identification of hard ticks (Ixodidea) found in livestock of Harnai District, Balochistan, Pakistan
}

Saqiba Bibi ${ }^{1}$, Nosheen Rafique ${ }^{1}$, Aasia Karim ${ }^{1}$, Muhammad Kamran Taj $^{2 *}$, Kiran Iqbal ${ }^{1}$, Asifa Bibi ${ }^{1}$, Muhammad Shafiq ${ }^{3}$, Gulshan Ghafoor $^{1}$, Aeysha Ghafoor ${ }^{1}$ and Ambreen Ijaz ${ }^{1}$

1. Department of Zoology, Sardar Bahadur Khan Women University, Quetta, Pakistan

2. CASVAB, University of Baluchistan

3. Department of Commerce, University of Baluchistan-Pakistan

*Corresponding author's email: kamrancasvab@yahoo.com

Citation

Saqiba Bibi, Nosheen Rafique, Aasia Karim, Muhammad Kamran Taj, Kiran Iqbal, Asifa Bibi, Muhammad Shafiq, Gulshan Ghafoor, Aeysha Ghafoor and Ambreen Ijaz. Prevalence and taxonomic identification of hard ticks (Ixodidea) found in livestock of Harnai District, Balochistan, Pakistan. Pure and Applied Biology. Vol. 9, Issue 4, pp2330-2338. http://dx.doi.org/10.19045/bspab.2020.90247

\begin{tabular}{|c|c|c|c|}
\hline Received: 28/03/2020 & Revised: 30/05/2020 & Accepted: 08/06/2020 & Online First: 08/07/202 \\
\hline
\end{tabular}

\section{Abstract}

Ticks cause considerable damage to the livestock in tropical and subtropical areas. Because of climatic and environmental changes, the frequencies of tick-borne infections are increasing day by day. This research trial displays an outline about the different species of hard ticks (Family; Ixodidae) found in sheep, goats, cows, buffaloes and camels in District Harnai, Baluchistanon. The study duration of the present research trial was from $1^{\text {st }}$ December 2018 to $1^{\text {st }}$ December 2019. Ticks were collected from different parts of the body and examined for species identification. Total 913 ticks were collected from livestock. Most susceptible animal was cow (65\%) followed by buffalo (55\%), camel (47.5\%), sheep (30\%) and goats (27.5\%). Prevalence with respect to season, it was noted that, in summer season all hosts i.e. cows, buffalo, camels, goats and sheep were found to be highly infested while in winter infestation was low. In the current research trial, the prevalence of tick was high in cattle as compared to other livestock of Harnai District, Baluchistan. Nine species of ticks were identified in the study area as Amblyomma variegatum, Amblyomma heberaeum, Rhipicephalus Boophilus, Hyalomma dromedarii, Rhipicephalus appendiculatus, Rhipicepalus boophilus microplus, Rhipicephalus Boophilus annulatus, Hyalomma anatolicum, and Ixodes rubicundus. The widely spread and most prevalent species of tick were Amblyomma heberaeum and Rhipicephalus appendiculatus, while Ixodes rubicundus was the least prevalent specie. Favorable climatic conditions may be one of the reasons of this high prevalence of ticks in District Harnai.

Keywords: Cow; District; Harnai; Ixodidae; Prevalence; Tick

\section{Introduction}

Economy of Pakistan mainly depends on its livestock production as chief provider of food [1]. The domesticated animals are the vital piece of the economy of Pakistan and viewed as the foundation of the rural economy as over $70 \%$ of the population lives in rural areas. People rely upon keeping domesticated animals for their survival [2]. 
Ticks are extremely well known specific group of obligate ectoparasites of birds, reptiles and mmamles. They have blood sucking feeding habit [3]. There are three types of ticks identified as hard ticks, soft ticks and nuttalliella [4].

The differences between male and female ticks are fallowing. The male have totally covered scutum and female covers only a portion of dorsal surface [5]. Ticks are economically responsible for great lasses in cattle farming worldwide [6].

Ticks are the specific type of ectoparasites, which suck blood from warm blooded animals and have a potential to transfer parasites mostly in animals and rarely in humans. These parasites cause serious loses by spreading pathogens among animal populations [7].

Ixodidae family is one of the biggest groups of parasitic ticks in which about 13 genera and 650 species have been recognized [8]. Ticks of Ixodidae family transmit various bacterial, protozoal, rickettsial, spirochaetal and viral pathogens. The ixodid tick species are the most common tick parasites found in ruminants. Ticks have been thought as the critical danger because of their sensitivity and toxicity to animals. Ticks cause considerable damage to the assets of cultivating community particularly in tropical and subtropical areas [2].

Because of climatic and environmental changes, the frequencies of tick-borne infections are increasing day by day. It was accounted in an investigation that $H$. aegyptium is highly prevalent in different natural environments, for example, backwoods, forests, steps and deserts in the Palearctic region, Middles East, Northern Africa, Balkans and Central Asia [7].

A solitary female engorged tick can cause loss of $0.5-2 \mathrm{ml}$ of blood, $8.9 \mathrm{ml}$ of milk and $1 \mathrm{~g}$ of body weight in ruminants daily. The worldwide economic loss due to tick invasion has been evaluated as US $\$ 14,000-18,000$ million every year and it causes loss of US $\$ 498.7$ million in India each year [9].
This research trial displays an outline about the different species of hard ticks (Family; Ixodidae) found in sheep, goats, cow, buffaloes and camels in District Harnai, Baluchistan, Pakistan. Beside these, the present examination was incorporated to know the prevalence of ticks in relation to the months of the year, diverse season of the year and age of the animal [9].

\section{Materials and methods \\ Study area}

Balochistan being the largest province of Pakistan, spreading over an area of 350,000 $\mathrm{sq} / \mathrm{km}$. This study was conducted at randomly selected livestock farms of districts Harnai in the Balochistan province, Pakistan. The area is canal irrigated and heavily populated with livestock.

\section{Study population}

The samples were collected from Cattle (40), Camel (40), Goat (40) and Sheep (40), of Harnai District of Balochistan.

\section{Study duration}

The study duration of the present research trial was from $1^{\text {st }}$ December 2018 to $1^{\text {st }}$ December 2019.

\section{Study design}

To identify and determined the prevalence of hard ticks in livestock, ticks were collected from upper, lower, anterior and posterior parts of the body and examined for species identification.

\section{Tick collection and preservation}

Livestock were thoroughly inspected for ticks from every part of the body (ear, eye, testis, udder, vulva, tail, memory gland, abdominal and anal area). 30\% alcohol was used to preserve ticks, after being separated from the host body.

\section{Tick processing and identification}

In lab separate the sample according to their specific features start the process including After boiling for 20-30 min in potassium hydroxide $(\mathrm{KOH})$, the observed ticks were then passed through a series of grading level of alcohol $(30 \%, 50 \%, 70 \%, 90 \%$ and $100 \%)$. Ticks were placed for 2 hours in each level of alcohol then transferred to the higher grade. Staining was done before transferring to $90 \%$ grade of alcohol. After 
$100 \%$, finally ticks were placed in xylol for 5 seconds and then clove oil for few seconds. Ticks were mounted from Canada balsam after placing on slide. After processing all ticks were identified with the help of a microscope by taxonomy keys [10].

\section{Sex determination}

On the basis of scutum on the dorsum, female ticks had been separated and all ticks were identified for genus and specie level.

Results

The most susceptible animal was cow $(65 \%)$ followed by buffalo (55\%), camel $(47.5 \%)$, sheep (30\%) and goat $(27.5 \%)$ as shown in (Table 1). The male and female were observed from every host i.e. cow, buffalo, camel, goat and sheep. It was noted that 48 males and 42 females were found infested (Table 1). Collectively, the prevalence rate was greater in males $(48 \%)$ as compare to females ( $42 \%)$.

Nine species of ticks were identified in the study area as Amblyomma variegatum, Amblyomma heberaeum, Rhipicephalus Boophilus, Hyalomma dromedarii, Rhipicephalus appendiculatus, Rhipicepalus boophilus microplus,
Rhipicephalus Boophilus annulatus, Hyalomma anatolicum, and Ixodes rubicundus. The widely spread and most prevalent species of tick were Amblyomma heberaeum and Rhipicephalus appendiculatus, while Ixodes rubicundus was the least prevalent specie (Table 2).

In cow 133 ticks were males and females were 179 . The total male: female ratio was (1:1.4), which showed dominancy of female ticks over males. in (sheep) 1:1.5,(cows) 1:1.2 and (camels)1:1.9 respectively.

Rhipicepalus Boophilus was observed in maximum number as larvae $\mathrm{N}$ (10) and nymp N (19) in while Amblyomma herbraeum was detected in highest number as adult $\mathrm{N}$ (72) (Table 3).

In summer season all hosts i.e. cows, buffalo, camels, goats and sheep were found to be highly infested while in winter infestation was low. In July high number of ticks were collected, which was followed by August (Table 4), while in February, minimum number of ticks were observed on cattle. This proved a direct association of tick's prevalence with increased temperature. Humidity and temperature may influence tick infestation.

Table 1. Prevalence of ticks in livestock of Harnai District, Balochistan

\begin{tabular}{|c|c|c|c|c|c|c|c|c|c|}
\hline \multirow{2}{*}{ Host } & \multicolumn{3}{|c|}{ Observed } & \multicolumn{3}{c|}{ Infested } & \multicolumn{3}{c|}{ Prevalence \% } \\
\cline { 2 - 10 } & M & F & Total & M & F & Total & M & F & Total \\
\hline Cow & 20 & 20 & 40 & 16 & 10 & 26 & 40 & 25 & 65 \\
\hline Buffalo & 20 & 20 & 40 & 9 & 13 & 22 & 22.5 & 32.5 & 55 \\
\hline Camel & 20 & 20 & 40 & 9 & 10 & 19 & 22.5 & 25 & 47.5 \\
\hline Goat & 20 & 20 & 40 & 6 & 5 & 11 & 15 & 12.5 & 27.5 \\
\hline Sheep & 20 & 20 & 40 & 8 & 4 & 12 & 20 & 10 & 30 \\
\hline Total & 100 & 100 & 200 & 48 & 42 & 90 & 120 & 105 & 45 \\
\hline
\end{tabular}

Table 2. Total no. of ticks and their percentage with respect to identified specie in various hosts in Harnai district, Balochistan

\begin{tabular}{|c|c|c|c|c|}
\hline Host & Total no of ticks & Species of ticks & No & Percentage \% \\
\hline \multirow{4}{*}{ Cow } & \multirow{3}{*}{312} & Amblyomma hebraeum & 23 & 7.37 \\
\cline { 3 - 5 } & & Amblyomma variegatum & 34 & 10.89 \\
\cline { 3 - 5 } & & Hyalomma dromedarii & 40 & 12.82 \\
\cline { 3 - 5 } & & Ixodes rubicundus & 35 & 11.21 \\
\cline { 3 - 5 } & & Rhipicepalus Boophilus & 97 & 31.08 \\
\cline { 3 - 5 } & & Rhipicepalus appendiculatus & 83 & 26.60 \\
\hline \multirow{2}{*}{ Buffalo } & 269 & Amblyomma hebraeum & 88 & 32.71 \\
\hline
\end{tabular}


Bibi et al.

\begin{tabular}{|c|c|c|c|c|}
\hline & & Hyalomma anatolicum & 44 & 16.35 \\
\hline & & Hyalomma dromedarii & 35 & 13.01 \\
\hline & & Rhipicepalus Boophilus & 40 & 14.86 \\
\hline & & Rhipicepalus appendiculatus & 62 & 23.04 \\
\hline \multirow{5}{*}{ Camel } & \multirow{5}{*}{106} & Amblyomma hebraeum & 13 & 12.26 \\
\hline & & Amblyomma variegatum & 19 & 17.92 \\
\hline & & Hyalomma dromedarii & 19 & 17.92 \\
\hline & & $\begin{array}{l}\text { Rhipicepalus boophilus } \\
\text { microplus }\end{array}$ & 23 & 21.69 \\
\hline & & Rhipicepalus aappendiculatus & 32 & 30.18 \\
\hline \multirow{4}{*}{ Goat } & \multirow{4}{*}{90} & Amblyomma hebraeum & 28 & 31.11 \\
\hline & & Hyalomma anatolicum & 1 & 23.33 \\
\hline & & Hyalomma dromedarii & 19 & 21.11 \\
\hline & & $\begin{array}{l}\text { Rhipicepalus boophilus } \\
\text { annulatus }\end{array}$ & 22 & 24.44 \\
\hline \multirow{4}{*}{ Sheep } & \multirow{4}{*}{136} & Hyalomma anatolicum & 34 & 25.00 \\
\hline & & Hyalomma dromedarii & 38 & 27.94 \\
\hline & & $\begin{array}{c}\text { Rhipicepalus boophilus } \\
\text { annulatus }\end{array}$ & 39 & 28.67 \\
\hline & & $\begin{array}{c}\text { Rhipicepalus boophilus } \\
\text { microplus }\end{array}$ & 25 & 18.38 \\
\hline Total & 913 & & & \\
\hline
\end{tabular}

Table 3. Different life stages of ticks in livestock of Harnai, District Balochistan

\begin{tabular}{|c|c|c|c|c|c|c|c|c|}
\hline \multirow[b]{2}{*}{ Host } & \multirow{2}{*}{$\begin{array}{c}\text { Total } \\
\text { No. } \\
\text { of } \\
\text { ticks } \\
\end{array}$} & \multirow[b]{2}{*}{ Species of ticks } & \multirow[b]{2}{*}{ No. } & \multicolumn{2}{|c|}{ Sex } & \multicolumn{3}{|c|}{ Life's stage } \\
\hline & & & & Male & Female & Larvae & Nymph & Adult \\
\hline \multirow{6}{*}{ Cow } & \multirow{6}{*}{312} & Amblyomma hebraeum & 23 & 8 & 15 & 3 & 6 & 14 \\
\hline & & $\begin{array}{c}\text { Amblyomma } \\
\text { variegatum }\end{array}$ & 34 & 11 & 23 & 4 & 8 & 22 \\
\hline & & Hyalomma dromedarii & 40 & 25 & 15 & 4 & 13 & 23 \\
\hline & & Ixodes rubicundus & 35 & 10 & 5 & 6 & 9 & 20 \\
\hline & & Rhipicepalus Boophilus & 97 & 43 & 54 & 10 & 19 & 68 \\
\hline & & $\begin{array}{c}\text { Rhipicepalus } \\
\text { appendiculatus }\end{array}$ & 83 & 36 & 47 & 6 & 15 & 62 \\
\hline \multirow{5}{*}{ Buffalo } & \multirow{5}{*}{269} & Amblyomma hebraeum & 88 & 31 & 57 & 5 & 11 & 72 \\
\hline & & Hyalomma anatolicum & 44 & 20 & 24 & 2 & 5 & 37 \\
\hline & & Hyalomma dromedarii & 35 & 20 & 15 & 4 & 6 & 25 \\
\hline & & Rhipicepalus Boophilus & 40 & 15 & 25 & 3 & 9 & 28 \\
\hline & & $\begin{array}{c}\text { Rhipicepalus } \\
\text { appendiculatus } \\
\end{array}$ & 62 & 20 & 42 & 7 & 17 & 38 \\
\hline \multirow{5}{*}{ Camel } & \multirow{5}{*}{106} & Amblyomma hebraeum & 13 & 8 & 5 & 2 & 4 & 7 \\
\hline & & $\begin{array}{c}\text { Amblyomma } \\
\text { variegatum }\end{array}$ & 19 & 6 & 13 & 3 & 5 & 11 \\
\hline & & Hyalomma dromedarii & 19 & 14 & 5 & 1 & 3 & 15 \\
\hline & & $\begin{array}{l}\text { Rhipicepalus boophilus } \\
\text { microplus }\end{array}$ & 23 & 15 & 8 & 2 & 6 & 15 \\
\hline & & $\begin{array}{c}\text { Rhipicepalus } \\
\text { appendiculatus }\end{array}$ & 32 & 11 & 21 & 5 & 7 & 20 \\
\hline \multirow{2}{*}{ Goat } & \multirow{2}{*}{90} & Ambylomma hebraeum & 28 & 9 & 19 & 3 & 4 & 21 \\
\hline & & Hyalomma anatolicum & 21 & 15 & 6 & 2 & 5 & 14 \\
\hline
\end{tabular}




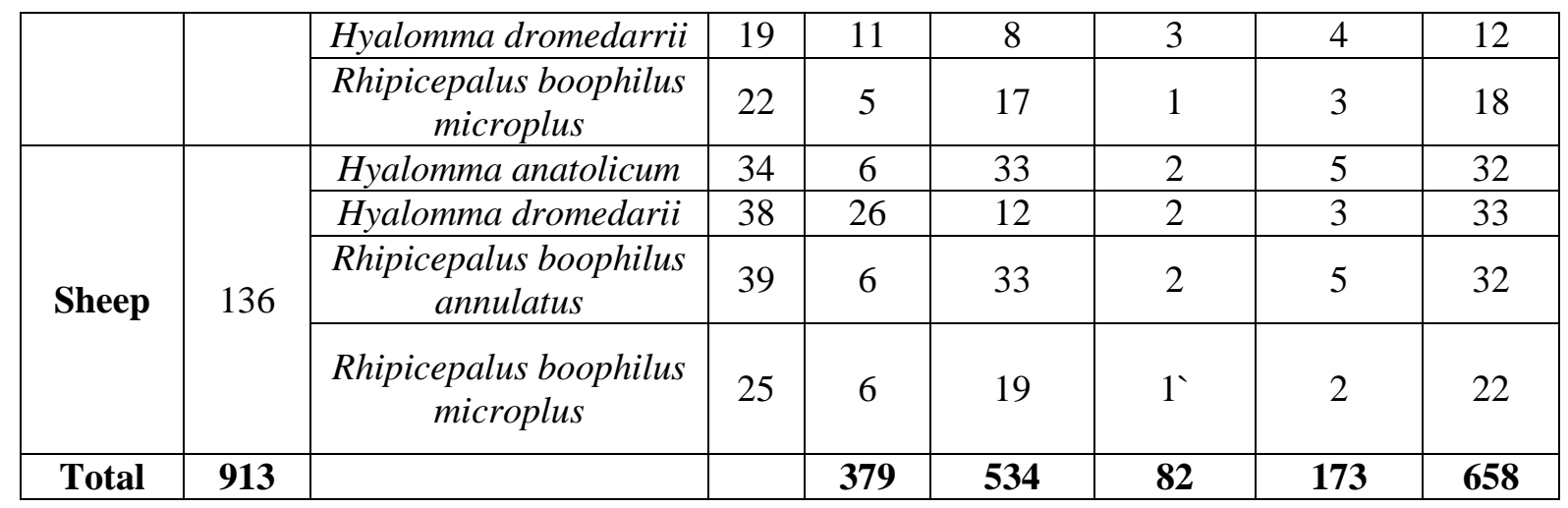

Table 4. Seasonal wise distribution of ticks in livestock of Harnai district, Balochistan

\begin{tabular}{|c|c|c|c|c|c|c|c|}
\hline \multirow{2}{*}{ Season } & \multirow{2}{*}{ Months } & \multicolumn{5}{|c|}{ Number of ticks } & \multirow[b]{2}{*}{ Total } \\
\hline & & Cow & Buffalo & Camel & Goat & Sheep & \\
\hline \multirow{3}{*}{ Spring } & March & 17 & 5 & 2 & 3 & 3 & 30 \\
\hline & April & 11 & 8 & 4 & 4 & 5 & 32 \\
\hline & May & 12 & 21 & 5 & 6 & 9 & 53 \\
\hline \multirow{3}{*}{ Summer } & June & 34 & 30 & 13 & 8 & 14 & 99 \\
\hline & July & 92 & 88 & 21 & 19 & 39 & 259 \\
\hline & August & 83 & 62 & 19 & 15 & 29 & 208 \\
\hline \multirow{3}{*}{ Autumn } & September & 23 & 19 & 16 & 12 & 12 & 82 \\
\hline & October & 18 & 15 & 10 & 11 & 10 & 64 \\
\hline & November & 17 & 9 & 9 & 6 & 8 & 49 \\
\hline \multirow{4}{*}{ Winter } & December & 3 & 7 & 5 & 4 & 5 & 24 \\
\hline & January & 1 & 3 & 1 & 1 & 1 & 7 \\
\hline & February & 1 & 2 & 1 & 1 & 1 & 6 \\
\hline & Total & 312 & 269 & 106 & 90 & 136 & $\begin{array}{c}\text { Grand } \\
\text { total } \\
=913\end{array}$ \\
\hline
\end{tabular}

\section{Discussion}

The most susceptible animal was cow (65\%) followed by buffalo (55\%), camel (47.5\%), sheep (30\%) and goat $(27.5 \%)$ as shown in Findings of Walker et al., $[10\}$ are in the line with these results, who reported tick infestation $33.7 \%$ in cattle, $22.8 \%$ in buffaloes, $16.67 \%$ in goats and $10.4 \%$ in sheep in N.W.F.P. Similar result was reported by Khan, [11] who observed highest susceptibility of cattle for tick infestation.

A total 100 male and female were observed from every host i.e. cow, buffalo, camel, goat and sheep. It was noted that 48 males and 42 females were found infested collectively, the prevalence rate was greater in males $(48 \%)$ as compare to females $(42 \%)$. This result is in the line with
Hitcheock, [12]. The authors stated the reason of increased rate of male prevalence that male animals are usually practiced in farming. They travel from one place to other and acquire tick infection [13]. Although in buffalos and camels, the rate of infestation was greater in females than males $(32.5 \%$ and $22.5 \%$ respectively). It can be presumed that increased concentration of prolactin and progesterone hormones in females may be one of the reason of this high prevalence of females. Furthermore, lactation and stress from pregnancy could contribute to increase susceptibility of female animals to infections.

Nine species of ticks were identified in the study area as Amblyomma variegatum, Amblyomma heberaeum, Rhipicephalus 
Boophilus, Hyalomma dromedarii, Rhipicephalus

Rhipicepalus boophilus microplus, Rhipicephalus Boophilus annulatus, Hyalomma anatolicum, and Ixodes rubicundus. The widely spread and most prevalent species of tick were Amblyomma heberaeum and Rhipicephalus appendiculatus, while Ixodes rubicundus was the least prevalent specie (Table 5). This further indicated that the finding of this tick in the area is in line with its wide spread occurrence in most parts of the country. Hyalommaand Rhicephalus had also been confirmed from elevated and hilly areas and from grasslands areas of Pakistan [14]. The authors examined 813 cattle in Gilgit Baltistan and Khyber Pakhtunkhwa. It was observed that the rate of prevalence of Hyalomma anatolicum and Rhipicephalus microplus was exceedingly high as compare to other species. In another study. Khalil et al. [15]. found Hyalomma as highly prevalentspeciewith a rate of $44.5 \%$ prevalence in buffaloes of Jampur District, South Punjab, Pakistan. Esmail \& Ahari, [16]; Radfar [17] also stated Hyalomma as dominating specie over other species of ticks.

In cow 133 ticks were males and females were 179 . The total male: female ratio was
(1:1.4), which showed dominancy of female ticks over males. in (sheep) 1:1.5, (cows) $1: 1.2$ and (camels) $1: 1.9$ respectively.

Rhipicepalus Boophilus was observed in maximum number as larvae $\mathrm{N}$ (10) and nymp $\mathrm{N}$ (19) in while Amblyomma herbraeum was detected in highest number as adult $\mathrm{N}$ (72).

In summer season all hosts i.e. cows, buffalo, camels, goats and sheep were found to be highly infested while in winter infestation was low. In July high number of ticks were collected, which was followed by August, while in February, minimum number of ticks were observed on cattle. This proved a direct association of tick's prevalence with increased temperature. Humidity and temperature may influence tick infestation [18]. Findings of Das, [1921] are also in the agreement of this result. The author observed a similar trend of tick's infestation in cattle and buffalo highest from June to September and lowest from November to February. Tadesse et al., [22] also observed July as the month of highest prevalence $(57.3 \%)$ and November as lowest (36.4\%). Sanjay et al. [23]' StutiVatsya et al., [24]; Gosh, et al. [25] reported rainy season as highly prevalent and winter as least prevalent season for cattle.

Table 5. Sex wise distribution of identified tick specie in livestock of Harnai District, Balochistan

\begin{tabular}{|c|c|c|c|c|c|c|}
\hline Host & $\begin{array}{l}\text { Total No. of } \\
\text { ticks }\end{array}$ & Species of ticks & No. & Male & Female & $\begin{array}{l}\text { Male /Female } \\
\text { ratio }\end{array}$ \\
\hline \multirow{7}{*}{ Cows } & \multirow{7}{*}{312} & Amblyomma hebraeum & 23 & 8 & 15 & $1.6: 1$ \\
\hline & & Amblyomma variegatum & 34 & 11 & 23 & $1: 2.0$ \\
\hline & & Hyalomma dromedarii & 40 & 25 & 15 & 1.6:1 \\
\hline & & Ixodes rubicundus & 35 & 10 & 25 & $1: 1.8$ \\
\hline & & Rhipicepalus Boophilus & 97 & 43 & 54 & $1: 1.2$ \\
\hline & & $\begin{array}{c}\text { Rhipicepalus } \\
\text { appendiculatus }\end{array}$ & 83 & 36 & 47 & $1: 30$ \\
\hline & & Total & 312 & 133 & 179 & \\
\hline \multirow{5}{*}{ Buffalo } & \multirow{5}{*}{269} & Amblyomma hebraeum & 88 & 31 & 57 & $1: 1.8$ \\
\hline & & Hyalomma anatolicum & 44 & 20 & 24 & $1: 1.2$ \\
\hline & & Hyalomma dromedarii & 35 & 20 & 15 & $1.3: 1$ \\
\hline & & Rhipicepalus Boophilus & 40 & 15 & 25 & $1: 1.6$ \\
\hline & & $\begin{array}{l}\text { Rhipicepalus } \\
\text { appendiculatus }\end{array}$ & 62 & 20 & 42 & $1: 2.1$ \\
\hline
\end{tabular}




\begin{tabular}{|c|c|c|c|c|c|c|}
\hline & & Total & 269 & 106 & 163 & \\
\hline \multirow{6}{*}{ Camel } & \multirow{6}{*}{106} & Amblyomma hebraeum & 32 & 11 & 21 & $1: 1.9$ \\
\hline & & Amblyomma variegatum & 19 & 6 & 13 & $1: 2.1$ \\
\hline & & Hyalomma dromedarii & 19 & 14 & 5 & $2.5: 1$ \\
\hline & & $\begin{array}{l}\text { Rhipicepalus boophilus } \\
\text { microplus }\end{array}$ & 22 & 15 & 8 & $1.8: 1$ \\
\hline & & $\begin{array}{c}\text { Rhipicepalus } \\
\text { aappendiculatus }\end{array}$ & 32 & 11 & 21 & $1: 1.9$ \\
\hline & & Total & 106 & 54 & 52 & \\
\hline \multirow{5}{*}{ Goat } & \multirow{5}{*}{90} & Amblyomma hebraeum & 28 & 9 & 19 & $1: 2.1$ \\
\hline & & Hyalomma anatolicum & 21 & 15 & 6 & $2.5: 1$ \\
\hline & & Hyalomma dromedarii & 19 & 11 & 8 & $1.8: 1$ \\
\hline & & $\begin{array}{l}\text { Rhipicepalus boophilus } \\
\text { annulatus }\end{array}$ & 22 & 5 & 17 & $1: 3.4$ \\
\hline & & Total & 90 & 40 & 50 & \\
\hline \multirow{5}{*}{ Sheep } & \multirow{5}{*}{136} & Hyalomma anatolicum & 34 & 8 & 26 & $1: 3.25$ \\
\hline & & $\begin{array}{l}\text { Rhipicepalus boophilus } \\
\text { annulatus }\end{array}$ & 39 & 6 & 33 & $1: 5.5$ \\
\hline & & $\begin{array}{l}\text { Rhipicepalus boophilus } \\
\text { microplus }\end{array}$ & 25 & 6 & 19 & $1: 3.1$ \\
\hline & & Hyalomma dromedarii & 38 & 26 & 12 & $2.1: 1$ \\
\hline & & Total & 136 & 46 & 90s & \\
\hline Total & 913 & & & 379 & 534 & 1:1.4 \\
\hline
\end{tabular}

\section{Conclusion}

In the current research trial, tick prevalence was observed in cattle from Harnai District, Baluchistan. Nine species of ticks were identified in the study area as Amblyomma variegatum, Amblyomma heberaeum, Rhipicephalus Boophilus, Hyalomma dromedarii, Rhipicephalus appendiculatus, Rhipicepalus boophilus microplus, Rhipicephalus Boophilus annulatus, Hyalomma anatolicum, and Ixodes rubicundus the widely spread and most prevalent species of tick were Amblyomma heberaeum and Rhipicephalus appendiculatus, while Ixodes rubicundus was the least prevalent specie. In general, due to unsatisfactory tick control measures and lack of awareness about effective control strategies, ticks were highly prevalent in cattle in the study area. Favorable climatic conditions may be one of the reason of this high prevalence of ticks in District Harnai. The ixodid tick have been thought as the critical danger to cattle because of their sensitivity and toxicity to animals and accountable for severe financial losses through impairment to hide and by spreading various diseases through blood sucking. Consequently, it is necessary to control tick infestation in cattle to reduce the loss. Use of acaricide could be a good mechanism to minimize tick infestation. Further studies on the impact of environment on tick infestation, other risk factors and as well as effective tick controlling strategies are suggested in the area as per current finding.

\section{Authors' contributions}

Conceived and designed the experiments: $S$ Bibi, N Rafiq \& MK Taj, Performed the experiments: S Bibi, K Iqbal, M Shafiq, Analyzed the data: S Bibi, N Rafiq \& MK Taj, Contributed materials/ analysis/ tools: S Bibi, A Bibi, G Ghafoor \& A Ghafoor, Wrote the paper: S Bibi, A Ijaz \& MK Taj.

\section{References}

1. Shahnawaz S, Ali M, Aslam MA, Fatima R, Chaudhry ZI, Hassan MU, \& Iqbal F (2011). A study on the prevalence of a tick-transmitted 
pathogen, Theileriaannulata, and hematological profile of cattle from Southern Punjab (Pakistan). Para Res 109(4): 11-55.

2. Rehman A, Nijhof AM, Sauter-Louis C, Schauer B, Staubach C, \& Conraths FJ. (2017). Distribution sof ticks infesting ruminants and factors associated with high tick prevalance in livestock farms in the semi-arid and arid argo-ecological zones of Pakistan. Para Vect 10(1): 190.

3. Rafique N, Kakar A, Iqbal A, Masood Z, \& Razzaq W (2015). Identification of Three Species of Ticks Hyalomma anatolicum Anatolicum, Hyalomma aegyptium and Dermacenterandersoni in Quetta City of Balochistan, Pakistan. Glob Vete 14(6): 842-847.

4. Rafiq N, Kakar A, Ghani A, Iqbal A, Achakzai WM, Sadozai S, \& Mengal MA. (2017). Ixodid Ticks (Arachnida: Acari) Prevalence Associated with Risk Factors in the Bovine Host in District Quetta, Balochistan. Pak J Zool 49(6).

5. Iqbal A, \& Nawaz M. (2007). Taxonomic studies of Haemaphysalis flava (Neumann), its seasonal prevalence and role in parasitic diseases of sheep/goat in Balochistan. Pak Entomol 29: 1-4.

6. Iqbal A, Iram S, Gul S, \& Panezai MA. (2016). Analysis of immune response in goats Capra hircuslehri against different doses of cement cone extract antigen taken from ticks (ixodidae) emulsified with different adjuvants. Pak J Zool 48(4).

7. Yilmaz AB, Kilinç ÖO, Adizel Ö, Bulum E, \& Yüksek N. (2018). Ticks collected from reptile species on Small Nemrut Mountain (Tatvan/Bitlis/Turkey). Med-Vete Medi Sci Prac 74(7): 445-44.

8. Monfared AL, Mahmoodi M, \& Fattahi R. (2015). Prevalence of ixodid ticks on cattle, sheep and goats in Ilam County, Ilam Province, Iran J para Diseas 39(1): 37-40.
9. Patel G, Shanker D, Jaiswal AK, Sudan V, \& Verma SK. (2013). Prevalence and seasonal variation in ixodid ticks on cattle of Mathura district, Uttar Pradesh. J para Diseas 37(2): 173-176.

10. Walker AR, Bouattour JL, Camicas AE, Pena IG, Horak AA, Latif RG, \& Pegram P. (2003). Ticks of domestic animals in Africa. A guide to identification of species. Biosci Report Atal Hout Nehter 74: 218-221.

11. Khan MN, Hayat CS, Iqbal Z, Hayat B, \& Naseem A. (1993). Prevalence of tick on livsestock in faisalabad. Pak Vet J 13(4): 182-184

12. Hitcheock LF. (1993). Resistence of cattle tick, to benzene hexachlloride. $J$ Agri Res 29: 41-49.

13. Soulsby EJL. (1982). Helminths, Arthropods and Protozoa of Domesticated Animals. 7th Ed., Baillier, Tindall and Cassel Ltd. London, UK. pp 765-76

14. Sajid MS, Iqbal Z, Shamim A, Siddique RM, Hassan MJU, \& Rizwan HM. (2017). Distribution and abundance of ticks infesting livestock population along Karakorum highway from Mansehra to Gilgit, Pakistan. $J$ Hell Vet Med Soc 68(1):51-58.

15. Khalil MI, Lashari MH, Akhtar MS. (2018). Prevalence Of Ticks Infesting Buffaloes In And Around Jampur District Ranjanpur, Pakistan. Fuu J Bio 8(2): 327-330.

16. Esmail NK, \& Ahari PV. (2005). Surveys of sheep and Goat Ticks in Savajbulagh and Abic Area. Abstract Book $5^{\text {th }}$ National Iranian Congress of Parasitology 15-17 November, Tehran, pp 178.

17. Radfar MH. (2005). Evaluation of Ticks Infestation in Cattle, Sheep, goat and Camels in South East Iran, (Keman). Abstract Book $5^{\text {th }}$ National Iranian Congress of Parasitology 1517 November, Tehran, pp 193.

18. Muchenje V, Dzama K, Chimonyo M, Raats JG \& Strydom PE (2008). Tick susceptibility and its effects on growth 
performance and carcass characteristics of Nguni, Bonsmara and Angus steers raised on natural pasture. Anim 2(2): 298-304

19. Wanzala W, Sika NFK, Gule S, \& Hassanali A. (2004). Attractive and repellent host odours guide ticks to their respective feeding sites. Chemo 14(3-4): 229-232.

20. Khan MH. (1996). Studies on Hyalomma Kumari Sharif, on goats. $J$ Vet Para 10 (2): 165-169.

21. Das SS. (1994). Prevalence of ixodid tick infestation on farm animals in Pantnagartarai of Uttar Pradesh. J Para Appl Anim Biol 3: 71-73.

22. Tadesse F, Abadfaji G, Girma S, kumsa B \& Jibat T (2012). Identification of tick species and Stheir preferred site on cattle's body in and around MizanTeferi, Southwestern Ethiopia. J Vet Medi Anim Healt 4(1): 1-5.

23. Sanjay K, Prasad KD, \& Deb AR. (2007). Seasonal prevalence of different ectoparasites infecting cattle and buffaloes. J Res 16(1): 159-163.

24. Stuti V, Yadav CL, Kumar RR \& Rajat G. (2008). Prevalence of ixodid ticks on bovines in foothills of Uttarkhand state: a preliminary report. Govind Ballabh Pant University of Agriculture and Technology, India. Ind J Anim Sci 78(1): 40-2.

25. Ghosh S, Patra G, Borthakur SK, Behera P, Tolenkhomba TC, Das M, \&Lalnunpuia, C. (2018). Prevalence of hard tick infestations in cattle of Mizoram, Ind. Biol Rhy Res 1-11. 